\title{
IMPLEMENTATION OF THE AGENDA FOR MEDIA SETTINGS AS WATCHDOG FOR LAW ENFORCEMENT EFFORTS THROUGH DIGITAL AND PRINT ARTIFACTS
}

\section{PELAKSANAAN AGENDA SETTING MEDIA SEBAGAI PENGAWASAN TERHADAP UPAYA PENEGAKAN HUKUM MELALUI ARTEFAK DIGITAL DAN CETAK}

\author{
Gede Moenanto Soekawati \\ gedemoenanto@univpancasila.ac.id \\ Kandidat Doktor Ilmu Komunikasi, Pasca Sarjana Fakultas Ilmu Komunikasi \\ Universitas Padjadjaran
}

Artikel diterima: 3 Januari 2020

Artikel direvisi: 3 Februari 2020

Artikel disetujui: 5 Februari 2020

\begin{abstract}
ABSTRAK
Peliputan media atas sejumlah kasus adalah implementasi agenda setting metode penyampaian informasi. Sejumlah informasi disampaikan berdasarkan fakta yang dikonstruksi sebagai realitas media. Di antaranya, kasus Tempo melawan Tomy Winata, keterlibatan wartawan Metro TV Hilman Mattauch terhadap kasus korupsi e-KTP oleh Setya Novanto, dan upaya yang dilakukan media sebagai watchdog dalam kasus Lutfi Alfiandi. Penelitian meneliti artefak digital dan tercetak, observasi, dan wawancara. Sejumlah pertanyaan penelitian adalah: 1. Bagaimana konstruksi media sebagai watchdog dalam kasus hukum antara Tomy Winata versus Tempo? 2. Bagaimana penerapan watchdog media dalam kasus penegakan hukum e-KTP? 3. Bagaimana penerapan watchdog media dalam kasus penangkapan dan penyiksaan yang dialami pelajar STM bernama Lutfi Alfiandi? Hasil penelitian terhadap artefak digital dan media cetak, wawancara, dan observasi adalah: 1. Implementasi pers sebagai pengawas kasus Tomy Winata di Tanah Abang dilakukan oleh Tempo, meski hasilnya Tempo mendapat konsekuensi kekalahan di meja hijau atas gugatan Tomy Winata. 2. Pelaksanaan watchdog dalam upaya penegakan hukum oleh Komisi Pemberantasan Korupsi (KPK) dilakukan terhadap kuasa media yang melibatkan Hilman Mattauch dari Metro $T V$ dan diungkap oleh media. 3. Peristiwa kasus polisi menangkap dan menyiksa Lutfi Alfiandi mendapatkan pelaksanaan agenda setting oleh media dalam peran watchdog sehingga korban yang semula dituntut hukuman tujuh tahun penjara dapat simpati publik mendorong majelis hakim memvonis bebas.
\end{abstract}

Kata kunci: Pengawas Pers, Penegakan Hukum, Liputan Media

\begin{abstract}
Several events received media coverage with an agenda-setting process which became a method of conveying information. Some information is conveyed based on facts constructed as media reality. Among them are the construction of media reality carried out in the Tempo case against Tomy Winata, the involvement of Metro TV journalist Hilman Mattauch in the e-KTP corruption case involving Setya Novanto, and the efforts made by the media as a watchdog in the Lutfi Alfiandi case. The research was conducted by examining digital and printed artifacts, observations, and interviews. Some research questions are 1 . How is the construction of the media as a watchdog in the legal case between Tomy Winata and Tempo? 2. How is the application of watchdog media in the case of e-KTP law enforcement? 3. How is the application of the media watchdog in the case of arrest and torture experienced by STM student named Lutfi Alfiandi? The results of research on digital artifacts and print media, interviews, and observations are 1. Implementation of the watchdog press to reveal Tomy Winata in Tanah Abang was carried out by Tempo, although the result was that Tempo suffered the consequences of being defeated at the court table by the lawsuit filed by Tomy Winata. 2. The implementation of watchdog in law enforcement efforts by the Corruption Eradication Commission (KPK) was carried out against the power of the media which involved Hilman Mattauch from Metro TV and was exposed by the media. 3. The police's arrest and torture of Lutfi Alfiandi resulted in the implementation of agenda-setting by the media in the role of a watchdog which succeeded in making the
\end{abstract}


victim who was sentenced to seven years in prison get public sympathy and was released when the verdict was handed down by the panel of judges.

Keywords: Watchdog Press, Law Enforcement, Media Coverage

\section{INTRODUCTION}

The construction of media reality in the amount of news is indeed very convincing because it has the power to make constructions of reality. Although the media do not always carry out activities based on the public interest, there are other interests, so that when they were sued in court, the media lost to the plaintiff and carried out some consequences because of the defeat (Cohen, 1963). Artefacts are traces or artefacts not only objects of knowledge, but they are also involved in cognition itself. Nobody argues that humans use artefacts in their cognitive practice where we count them on paper or with electronic devices and memory aids from individual shopping lists to monuments that perpetuate cultural memories are ubiquitous. In recent years, a collection of loosely linked approaches has characterized artefacts that are much more closely involved in this process than the mundane complex use of embodied, active, located, distributed, and extended approaches to cognition might suggest. (Wilson, 2009)

Media is a tool for communicating through mass media, online media and social media, leaving traces or artefacts. In the end, media traces can become artefacts for conducting research related to history, culture, social, politics, law, anthropology, sociology, and especially communication through text, photos, videos and some other media (Adorno, 1976). The lawsuit incident at the South Jakarta District Court referred to the coverage of the Southeast Sulawesi Governor Ali Mazi's denial of Tommy Winata's involvement in opening a gambling business there. Another news that was questioned was the news entitled "From EdyTansil to Zarima", which was published on the February 6, 2003 edition. Januardi said that the news was considered to have defamed his client. The Koran Tempo report is considered to have drawn the wrong conclusion and identified Tommy Winata with the gambling business. The lawsuit at the Central Jakarta District Court was addressed to
PT Tempo Intimedia Tbk, Fikri Jufri, Bambang Harymurti and several journalists who contributed to the writing, Is there Tommy in Tenabang? Which was published in the March 3, 2003 edition of Tempo Magazine. Another piece of news that became the basis for the lawsuit at the Central Jakarta District Court was the one published on Detik.com on March 12, 2003, entitled "Violence Against Tempo According to Ahmad Taufik's Testimony".

For the second time, the court won Tomy Winata's lawsuit against Tempo. Tempo's attorneys assessed that the panel of judges had a low appreciation for the press. Interestingly, the chairman of the panel of judges, in this case, was the judge who acquitted David A Miauw. The panel of judges at the Central Jakarta District Court, consisting of Sunaryo, Panusunan Harahap and Ridwan Mansyur, granted businessman Tomy Winata's lawsuit against the company and Tempo people. In the words readout, the panel of judges obliged Tempo to pay compensation of Rp. 500 million (Tempo, 2004). In addition, the defendants were required to pay forced money of Rp. 300,000 per day if they failed to implement the verdict. Defendants were also required to state apologies in three newspapers, namely Media Indonesia, Koran Tempo and Warta Kota. The same request must be published in Tempo magazine for half a page for three consecutive days.

Andreas Harsono stated that he had an interesting story about the Tempo versus Tomy Winata dispute. Two days after the Tempo office was demonstrated by Tomy's supporters, I sat at the table with one of the Tempo editors. We compare what we hear about the incident. It's sad. Bambang Harymurti, Chief Editor of Tempo, was insulted by the demonstrators. The head was punched, the stomach was punched. The demonstrators were angry with intimidation. The editor of Tempo said that the beatings of Bambang and other Tempo journalists had to be countered with political movements. Not by 
force. Not even with diplomacy (Harsono, 2003).

This phenomenon explains the relations between the press and the public and the judicial authority. Tomy Winata is categorized as a public, which has a profession as an entrepreneur. In the research conducted, it will be seen in relation to the public agenda, the policy agenda (judiciary), and how the media agenda makes efforts to capture reality in accordance with the agenda designed by the media (McCombs \& Shaw, 1972).

Meanwhile, efforts to control power by the media were carried out by Najwa Shihab by conducting exclusive interviews which were later broadcast on YouTube. The setting agenda carried out was an effort to prevent a suspect STM student demonstration, Lutfi Alfiandi, from the actions he experienced in detention by unscrupulous officers (Shihab, 2020). Lutfi Alfiandi, the bearer of the redand-white flag during the \#ReformasiDikorupsi action was forced to admit to throwing stones while undergoing questioning. Insisting not to do this, Lutfi was beaten and electrocuted by the authorities. Finally, Lutfi Alfiandi stated that he admitted that he was under duress, under pressure (Najwa, 2020).

The artefact of the media setting agenda in the next supervisory function is the legal process of the e-KTP case which, among others, involved several names including the Chairman of the DPR, Setya Novanto, at that time, the agenda carried out by the media was to reveal the parties involved in the corruption case. Several media are active in reporting on the corruption case involving some officials and popular names who are widely known to the public. In a news series entitled Hilman Paper, some media revealed how journalists and media were involved in the case of law enforcement on the electronic KTP or referred to as the e-KTP.

Before the Setya Novanto accident, Hilman was stopped by Metro TV on June 16, 2016. However, he was re-assigned as of November 7, 2016. The disappearance of SetyaNovanto yesterday became a public concern. Wednesday night (16/112017), when Corruption Eradication Commission investigators came to his residence at Jalan Wijaya
XIII, Kebayoran Baru, South Jakarta, he suddenly disappeared. It is not known where Novanto is. However, the next day, last Thursday night (17/11/2017), he reportedly had an accident when he was leaving for the Metro TV Studio in Kedoya, West Jakarta. The car he was riding in, the Toyota Fortuner B 1732 ZLO, hit a power pole in Permata Hijau, South Jakarta. The driver, based on the police statement, Hilman Mattauch, which Metro TV has confirmed as his contributor. His name immediately came into the spotlight for driving the wretched Fortuner. Moreover, shortly before the accident, Hilman had just had a direct teleconference with the Speaker of the DPR on Prime Time Metro TV (Tirto.id, 2017).

The implementation of the agenda setting is commonly done by the media in carrying out their supervisory or watchdog function. Agenda setting theory and secondlevel agenda setting theory, framing, are both relevant and similar in showing how society is influenced by the media, but they represent different processes of influence. Someone tells us what information to process and another tells us how to process that information. Framing theory, an extension of agenda setting, explains how the "attitude" a media article can take can influence viewers' perceptions. McCombs et al (1997) show that agenda-setting research at the second level is associated with salient 'attribute' effects, whereas first-level agenda setting illustrates salient 'problem' effects (Balmas M., 2010).

The implementation of watchdog by the media has been identified in cases of land eviction in Temon Village and Glagah Village, which are in Kulonprogo, Yogyakarta, Indonesia in a research conducted by Gede Moenanto Soekowati (Soekowati, 2019). In this connection, the study carried out is a qualitative study concerning which the press is expected to function as oversight and control of power. Qualitative research is carried out by observing, interviewing, and studying documents. 1. How is the existence of journalism supervision in the practice of journalism in land evictions for NYIA airport? 2. Why do residents of Temon Village and Glagah Village reject the eviction of land for NYIA airport? 3. How is the government's 
policy in evicting land for the construction of the NYIA Airport? The results of the research carried out are. 1. Events reported the media confirms the role of supervision journalism in mentoring very large community. 2. People do not feel they have defended by the media in Yogyakarta, but the news is massive carried out by national media published in Jakarta. 3 . Government assessing the construction of the NYIA Airport must be carried out by stating provide appropriate compensation to the people of Temon Village. (Soekowati, 2019)

\section{LITERATURE REVIEW}

The hierarchy of influence of media content that occurs is the influence internally and externally. There are 5 levels of influence that influence media content including media routines, individuals, financiers, ideology, and external influences. The influence of individual media workers (individual level), the influence of media routines (media routines level), the influence of media organizations (organizational level), the influence of ideology (ideology level), and influence from outside the media or outside the media level (Reese, 1996). The openness of information and democracy in Indonesia that has occurred since 1998 has become a moment of information disclosure and press freedom so that the public should fully benefit from this. Meanwhile, the legislative body consists of representatives of the people or members of the People's Representative Council (DPR). In the DPR there are commissions, among which are the liaison with law enforcement agencies (judiciary) and a number of ministries in the ranks of government. In addition, the DPR also liaised with commissions such as the Corruption Eradication Commission (KPK), the Judicial Commission (KY), and the Indonesian Broadcasting Commission (KPI). Because of the strength of the seats of power in the legislative and executive branches, there are also judiciary or authority institutions related to law enforcement.

The authority for law enforcement is attached to the prosecutor and the police who are members of the prosecutor's office and the police. To complement it there is also the
Corruption Eradication Commission (KPK). Related to this, there is also authority beyond the three pillars of power to create a democratic state as manifested in Indonesia so far. The existence of the press or mass media as the fourth pillar in a democratic country is urgently needed (Kohut, 2001). Although, there are some people who add the fifth estate which consists of social media, for the time being, the fourth power, namely the mass media is considered more dominant because it plays a role in confirming information as truth that is categorized and believed by society as a guideline for truth is the press or mass media as the fourth power. In fact, there are also businesses or entrepreneurs that generally intersect with law enforcement, licensing, and the business world that pursues the maximum profit or profit.

The business world is divided into various forms, including press companies or mass media in which the press is one of the pillars for realizing a clean and authoritative government with the main priority of realizing social justice for all Indonesian people. Therefore, as the pillars of a democratic state, the four pillars of power should be able to work together to create a democratic state in the real sense where the forms of power should be able to control each other so that there is no abuse of power or abuse of power.

Control over those who have the authority to exercise control needs to be realized, among others, by means of regulations and regulations that support the implementation of mass media as the fourth power. The role of entrepreneurs and the business world in the abuse of power may occur because the business world is close to the center of power so that in order to launch its business world, there is often an affair between the legislative, executive, judicial, and business powers. As Lord Acton said: "Power tends to be corrupt, absolute power, corrupts absolutely". Therefore, every form of abuse of power must be prevented, among others, by realizing the functions of power in the four pillars of democracy (Peter V.A., 2014). Watchdog journalism plays a role in informing the public about events in institutions and society, especially in situations where a large part of society would demand a 
change in response. These activities may involve Public official fact-checking reports. Interview community leaders and challenge them with problems or concerns. Overrides reporting to gather information from meetings that the general public may not attend, and to observe it on the ground within the wider community.

Agenda setting is a step taken, especially by the media in carrying out the news. With the agenda-setting, the media can carry out the stages to carry out the agenda that has been announced, so that they can achieve the goals expected by media institutions. By compiling the media agenda, it is hoped that it will be in line with the policy agenda and the public agenda so that the construction of reality by the media is expected to be in line with the public interest.

The journalistic investigation, which involves gathering information in one story over a long period. Like a literal guard dog that barks at the sight of an intruder, the role of watchdog engages the other person whenever a problem is detected. Common subjects are government decision-making processes, illegal activities, immorality, consumer protection issues, and environmental degradation. Watchdog journalism can be found in various news media such as radio, television, internet, and print media which can be seen as the unique strengths of newspapers and new media with concepts such as for weblogs and citizen journalism. Supervising journalists are also called custodians, social control agents, or moral guards.

The role of a supervisory journalist can be either a protector or a guardian. The role of watchdog journalists as guardians is to inform citizens about the information they must have to prevent abuse of power and to warn citizens about the people who commit such acts (Kosicki, 1993). To perform their role as watchdogs, journalists must distance themselves from the forces and challenge them, as opposed to propagandist journalists, who are loyal to the ruling elite and the ruling elite. Because of the distance of powers and the supervisory function, surveillance journalism is often formalized as a fourth pillar or is used in the context of the term (Bartels, 1996).
The topic arrangement for watchdog journalism is broad and includes "personal scandals, financial misconduct, political corruption, enrichment in public office, and other types of wrongdoing." To expose mistakes, monitors aim to "find hidden evidence". The aspects mentioned above are necessary for the role of the watchdog journalist to help maintain order and prevent chaos.

Released to be a watchdog, journalism, dedicated to objectivity, neutrality, fairness, and impartiality, is one of the four cultures of journalism identified in a study conducted by communications researchers Thomas Hanitzschand others, between 2007 and 2011. The study compares 2,100 active journalists worldwide. This is next to the idea of a journalist as a populist disseminator, critical change agent, or opportunist facilitator.

The purpose of this research is to create a better understanding of journalistic and journalistic culture. The study detected four global professional millennials of journalists: populist knowledge spreaders, separate monitors, critical change agents, and opportunist facilitators. Separate supervisors are separate observers. Apart from the supervisory functions described earlier, separate supervisors are not interventionist but are not involved. To achieve that status he must be objective, neutral, and impartial.

However, because of his supervisory function, he articulated his skeptical and critical attitude towards government and business elites. The separate surveillance environment was accredited as a prototype for western journalism. The countries in which the environment was dominated at the time of this study were Germany, Austria, United States, Switzerland, and Australia. In practice, watchdog journalism can lead to successful resignations of power holders. Notable examples include Bob Woodward and Carl Bernstein's reporting of the Watergate scandal to The Washington Post and the resignation of US President Richard Nixon in 1974. Another more recent example occurred in the Philippines, where President Joseph Estrada was arrested and resigned in 2001. The daily newspaper, the Pinoy Times, covered the Estrada case and the overthrow of Estrada. In 
countries that guarantee press freedom, watchdog journalism can be a very effective external control mechanism against corruption.

However, watchdog journalism mechanisms could also work in countries that deprive press freedom. A journalist in an authoritarian context may not be able to cover all topics, but can still find important journalistic niches. For example, in China where a free press is still not established or guaranteed the idea of the press as a watchdog of power is embedded in the journalist's selfdefinition.This makes a difference to whom criticism is directed. Journalists can criticize the abuse of power by individuals even when criticism points to major state policies that are disliked and discouraged by established journalists. In a free society, the idea of the media as the eyes and ears of society is widely accepted.

The concept of watchdog journalism cannot be separated from criticism. The entire field of watchdog journalism has declined over time and the journalism section has and in 2005 observers asserted that the current period is "not the reporting time of rich watchdogs in any media". It comes with a framework and issues many journalists are interested in reflecting on the status quo, rather than radically challenging it. This decline, however, cannot lead to the presumption that there are not enough important topics to write about or report on (Lang, 1981). In fact, the opposite is the case, and there's quite a bit of material to work with. While watchdog journalism in the US helped force Nixon out of office in 1974, the situation presented itself in 2003. During the Iraq war, some of the media that were founded turned out to take a more pro-war stance without adequately fulfilling their function of critical watchdog. Many professionals in the media do not appear to be in their role to challenge the government. Critics blame sections of the public in general, however, because their interest in watchdog journalism is impermanent and fleeting. They also see the role of watchdog journalism as being driven by its own interests and not by the desire to protect the public interest.

The agenda-setting theory describes the ability of the media to influence the interests placed on public agenda topics. With agenda- setting being a social science theory, it also tries to make predictions. This means that if the news item is closed frequently and stands out, the audience will consider this issue more important. Agenda setting theory was formally developed by Max McCombs and Donald Shaw in a study of the 1968 American presidential election. In the 1968 Chapel Hill study, McCombs and Shaw showed a strong correlation coefficient between 100 Chapel Hill residents, according to North Carolina, which was an election issue. the most important and what the local and national media news reports are the most important issues (McCombs M. , 1993).

By comparing the importance of issues in news content with people's perceptions of the most important election issues, McCombs and Shaw can determine the extent to which the media determine public opinion. Since the 1968 study, published in the 1972 edition of the Public Opinion Quarterly, more than 400 studies have been published on the agendasetting function of the mass media and the theory remains relevant. Agenda-setting theory can be traced to the first chapter of Walter Lippmann's 1922 book, Public Opinion. In that chapter, The World Outside And The Pictures In Our Heads, Lippmann argues that the mass media is the main link between events in the world and the images in the minds of people. Without using the term agenda-setting, Walter Lippmann wrote of what we now call agendasetting. Following Lippmann, in 1963, Bernard Cohen observed that the press "may not be successful all the time in telling people what to think, but it is riveting in telling its readers what to think (Cohen, 1963).

The world will look different with different people. Cohen continued, depending on the maps drawn by the writers, editors, and publishers of the papers they read. By the early 1960s, Cohen had articulated ideas that led to McCombs and Shaw's formalization of agenda-setting theory. Rogers and Dearing in Agenda Setting Research, Where has Been, Where is it Going, explain, even though Maxwell McComb already has an interest in the field, he was exposed to Cohen's work, while serving as a faculty member at UCLA, and it is Cohen's work that greatly influenced him. and then, Donald Shaw. The agenda- 
setting concept was launched by McCombs and Shaw during the 1968 presidential election in Chapel Hill, North Carolina. They examined Lippmann's idea of the construction of images in our heads by comparing issues of the media agenda with key issues of undetermined voter agendas. They found evidence of agendasetting by identifying the importance of the news agenda highly correlated with the agenda of voters. McCombs and Shaw were the first to provide the field of communication with empirical evidence showing the power of the mass media and their influence on the public agenda. The empirical evidence also gives this theory its credibility among other social scientific theories (McCombs \& Shaw, 1972).

A relatively unknown scholar named G. Ray Funkhouser conducted a study very similar to McCombs and Shaw around the same time the authors were formulating his theory. The three scientists - McCombs, Shaw, and Funkhouser - even presented their findings at the same academic conference. Funkhouser's articles were published later than McCombs and Shaw's, and Funkhouser did not receive as much praise as McCombs and Shaw for finding an agenda-setting. According to Everett Rogers, there are two main reasons for this.

First, Funkhouser didn't officially give the theory a name. Second, Funkhouser didn't pursue his research far past the original article. Rogers also points out that Funkhouser was geographically isolated at Stanford, cut off from interested researchers, while McCombs and Shaw got others interested in agendasetting research. Agenda setting, as stated by Rogers and Dearing, is the creation of public awareness and attention to important issues by the news media. Besides, agenda-setting describes how the media tries to influence viewers and establishes hierarchies of news prevalence. Two basic assumptions underlie most research on agenda-setting: the press and media do not reflect reality; they filter and shape it; Theconcentration of the media on several issues and subjects leads the public to consider these issues more important than other issues.

This core statement is made by measuring the change in significance through the use of surveys with more frequent news coverage. One of the most important aspects of the concept of the role of the agenda in mass communication is the time frame for this phenomenon. Also, different media have different potential for agenda-setting. From an agenda-setting perspective, the analysis of the relationship between traditional media and new cyberspace has seen increasing momentum.

Three types of agenda-setting: Research on the effect of agenda-setting compares the importance of issues in news content with public perceptions of the most important issues, and then analyzes the extent of this influence by media coaching. There are three models assumed by Max McCombs: the consciousness model, the priority model, and the salience model. Most of the investigations have focused on these three models.

In this study, the dependent variable is the media agenda, public agenda, and policy agenda as listed in the following section.

Rogers and Dearing identified three types of agenda-setting: Public agenda setting, in which the public agenda is the dependent variable (traditional hypothesis); media agenda setting, where the media agenda is treated as a dependent variable (agenda building); policy agenda setting, where the agenda of elite policymakers is treated as the dependent variable (political agenda-setting).

Mass communication research, Rogers and Dearing, argues, has focused on setting public agendas, for example, McCombs and Shaw, 1972, and setting media agendas, but has largely ignored policy agenda setting, which political scientists study primarily. Thus, the authors suggest that mass communication experts pay more attention to how the agenda of the media and the public can influence the agendas of elite policy makers; for example, scientists should ask where the president or members of the US Congress get their news and how this affects their policies (McCombs \& Shaw, 1972).

Writing in 2006, Walgrave and Van Aelst took Rogers and Dearing's suggestion, creating a preliminary theory of political agenda-setting, which examines the factors that might influence the agendas of elite policymakers. Agenda setting occurs through a cognitive process known as "accessibility". 
Accessibility implies that the more frequently and frequently the news media covers an issue, the more examples of that issue the audience's memories can access.

When respondents are asked what is the most important problem facing the country, they respond with the most accessible news publication on memory, which is usually the issue most focused on the news media. The agenda-setting effect is not the result of receiving one or more messages but is due to the overall impact of a large number of messages, each of which has different content but all dealing with the same general issue. The coverage of the mass media in general and agenda-setting in particular also have a strong impact on what people think that other people think and hence they tend to attach more importance to long-standing issues. Covered by the mass media. This is also called the schemata theory. In psychology and cognitive science, schemas (schemas or plural schemas) describe patterns of thought or behavior that organize categories of information and the relationships between them.

As more and more scientists published articles on agenda-setting theory, it became clear that the process involved not only the active role of media organizations but also public participation and policymakers. Rogers and Dearing illustrate the difference between agenda-setting and agenda setting based on the dominant role of the media or the public. So "setting" an agenda refers to the effect of the media agenda on society, shifting the media agenda to the public agenda, while "building" an agenda includes "some degree of reciprocity" between the mass media and society in which the media and public agendas influence public policy.

According to Sun Young Lee and Daniel Riffe, agenda formation theory speculates that the media do not operate in a vacuum. The media agenda is the result of the influence that certain powerful groups have as a subtle form of social control. Journalists have limited time and limited resources that can contribute to external sources involved in the regulatory modeling process of the news media, and some scientists have tried to reveal the relationship between information sources and the news media agenda, investigating who builds media event schedules. Many sources can participate in this agenda-setting process in a variety of ways, but researchers have been most interested in the effectiveness of information aids such as media kits and press releases in news media agendas, and this is a measure of the success of organizational public relations efforts.

Berkowitz in Kennamer's book, Who Sets the Media Agenda, has applied a more nuanced analysis of agenda-setting and agenda-building theory by introducing the requirements for setting policy agendas and setting policy agendas. He argues that while scientists only investigate the linkages between media and policymakers, it is still appropriate to use the idea of setting the policy agenda. However, when the focus is placed not only on the personal agenda of the policymaker but also on important salient issues where the media represent only one indicator of public sentiment, Berkowitz suggests talking about the policy agenda. Some groups have easier access than others and are therefore more likely to have their demands placed on the agenda than others. For example, policymakers are more influential than an entire group of news sources because they better understand journalists' need for reliable and predictable information and their definition of new stories (David H. W., 2017).

Cobb are seen to have made decisionmakers even more important, claiming that in order to be in trouble for achieving agenda status, it must be supported by at least some of the top decision-makers because they act as guardians of the formal agenda. They also emphasized that certain figures in the media can act as opinion leaders and bring media coverage to certain issues. Governmentaffiliated news sources have a higher success rate on the media agenda and have been found by a number of scientists to be the most frequent sources at the local, state, and national levels (Cobb, 1971).

Meanwhile, Hilgarten and Bosk, in the Journals of Politics, explained that news sources can also provide problem definitions, thereby determining the requirements for future discussions and framing problems in a certain way. What interpretations of "reality" will dominate public discourse have 
implications for future social problems, for the interest groups and policymakers involved, and for the policy itself. For example, Gusfield argues that road fatalities related to alcohol consumption can be interpreted as the problem of irresponsible drunk drivers, insufficient car accidents rarity, overly dependent car transportation systems, poor road design, excessive emphasis on drinking. in social adults. life. Different ways of framing situations can compete for acceptance as authoritative versions of reality, consequently spurring competition between information sources for the definition of an issue. A very powerful source of information can even influence whether an issue gets any media attention.

Berkowitz explains, media relations and policymakers are symbiotic and controlled by a shared culture of unofficial ground rules because journalists need access to official information and policymakers need media coverage; However, the needs of journalists and policymakers are often inappropriate because of their different orientations at the time because the most powerful sources are in the best situation and react more slowly when a crisis or disaster occurs. Consequently, policymakers who understand the rules of this culture are best able to set their agenda and issue definition. On the other hand, the media also influence policymakers when government officials and politicians pay attention to the media attention given to an issue as an indirect expression of the public interest in this issue (Berkowitz, 1992).

Several studies provide evidence that the internet community, particularly bloggers, can push their own agenda onto the public agenda, then the media agenda, and finally the policy agenda. In the most comprehensive study to date, Wallsten tracked mainstream media coverage and blog discussion on 35 issues during the 2004 presidential campaign. Using time-series analysis, Wallsten found evidence that journalists discuss issues that bloggers blog about. There is also some anecdotal evidence to suggest that bloggers exert influence on political agendas. For example, in 2005, Eason Jordan, CNN's chief news executive, abruptly resigned after being besieged by the online community after saying, according to various witnesses, that he believed the United States military had pointed their muzzles at journalists in Iraq and killed 12 in between.

Likewise, in 2002, Trent Lott had to step down as majority leader of the Senate because of his inappropriate racist comments that were widely discussed in the blogosphere. A number of bloggers are attracting attention not only to expel journalists and politicians. An online investigation into a technical problem with an electronic voting machine started by activist Bev Harris in 2003 has finally forced traditional media to tackle the problem of electronic performance malformations. This in turn led Diebold, the company that manufactured this machine, to find out what was wrong and take action to correct it. In an attempt to overcome the mirror-reflective effect of agenda-setting implying the direct influence of media agendas on audiences, some scientists have suggested that agenda-setting models should include individual/collective audience characteristics or real-world conditions that are likely to influence the importance of the problem. They find that specific individual and group characteristics tends to act as a contingent condition of media impact and proposes an audience effect model.

According to the audience effects model, media coverage interacts with preexisting sensitivities to produce a change in problems. Thus, media effects depend on the specific characteristics of the audience issue. For example, for high-sensitivity audiences who are most affected by a particular problem or problem, the significance of the issue increases substantially with news exposure, while the same exposure has little effect on the other groups. Erbring, Goldenberg, and Miller have also shown that people who don't talk about political issues are more subject to agenda setting because they rely more heavily on media content than on those who receive information from other sources, including their colleagues and friends.

Another factor that causes variations in the correlation between the media and the public agenda is whether an issue stands out or not; that is, whether it has a high or low problem threshold. The standout or problems 
with low thresholds are generally problems that affect almost everyone and with which we can have some kind of personal experience (eg citywide crime or rising gasoline prices). Due to their relationship to personal matters, these issues have almost attracted the attention of the political elite as well as the news media. Moreover, with this type of problem, the problem will become a general problem even without the attention of the news media (Lang, 1981).

\section{METHODOLOGY}

Qualitative research methods have data collection techniques, namely interviews, observation, and documentation. The research carried out on the Tempo and Tomy Winata cases used several pieces of literature related to these cases. Research on demonstrations of STM students and students to reject the revision of the KPK Law was carried out using interviews, observation, and documentation techniques. Meanwhile, research on law enforcement in e-KTP corruption cases was carried out using interviews and documentation techniques.

Data collection techniques in qualitative research include the identity and role of informants and the information conveyed is valuable, so researchers must have the responsibility to treat self-identity and information conveyed by informants. Attempts to provide understanding are made with care and caution. Meanwhile, the identity and information of the informants are carried out as the media coverage technique is open or closed to the public, depending on the agreement between the researcher and the informant written in the agreement form between the researcher and the informant. Researchers may reveal their identities as long as the informants agree and researchers must also respect the decision if the informants want their identity to be protected. In collecting qualitative research data, the researcher should get permission either in writing or orally so that the research does not violate the norms that the informant or the research object may adhere to (Denzin, 2009).

Qualitative research stated by Steven J Taylor, 1998, is a descriptive study and tends to use analysis. Process and meaning (subject perspective) are emphasized more in qualitative research. The theoretical basis is used as a guide so that the focus of the research is to follow the facts in the field. Also, the theoretical basis is useful for providing an overview of the research background and as material for discussion of research results. In qualitative research, the researcher departs from the data, makes use of the existing theory as material to explain, and ends with the theory (Soekowati, 2019).

The agenda-setting theory in this study explains the role of the public in the agendamaking process. The agenda-setting perspective is considered important not only for the mass media and policymakers but also for social processes, the interdependent relationship between concerns that arise in the social environment, and the vitality of the governance process. So according to Cobb and Elder, an agenda-setting framework makes allowances for continued mass engagement and extends the reach of recognized influence on the public policy-making process. Although the public has a place on the list that may influence the media agenda, they do not think they are strongly shaping the media agenda. It seems more correct to raise the possibility that when journalists see their importance for story ideas, they are trying to predict the needs of their audience.

This idea of mass involvement became increasingly prominent with the advent of the internet and its potential to turn everyone into pamphlets. The agenda-setting by the public influences the policy agenda and the media agenda. The increased role of citizens in agenda setting highlights new directions in traditional agenda-making research. This condition occurs because the general public can now make their media. Social media has changed the way people see and feel things in today's world. Mass involvement in social media allows the general public's voice to be heard. Comments and replies provide the potential for people to respond to your thoughts or open new doors for conversation.

Kim and Lee note that agenda-setting research on the Internet differs from traditional agenda-setting research in the respect that the Internet competes with traditional media and has a large capacity for content and user 
interactivity. Lee, Lancendorfer, and Lee argue that opinions on public issues are posted on Internet bulletin boards or Usenet newsgroups by Netizens, and their opinions then form an agenda where other Netizens can sense the salient issues. Scholars also state that the Internet plays a role in shaping the opinion of Internet users and public spaces. Kim and Lee studied internet-mediated agenda-setting patterns by conducting a case study of 10 cases that had a strong ripple effect in Korea for over 5 years (from 2000 to 2005). Scientists found that a person's opinion can be disseminated through various online channels and can synthesize public opinion that influences news coverage. Their study demonstrates a 'reverse agenda effect', meaning that a public agenda can set a media agenda.

Maxwell McCombs also cites reverse agenda setting in his latest textbooks as situations where public attention sets the media agenda (McCombs M. , 1993). According to Kim and Lee, agenda building via the Internet takes the following three steps: 1) A ripple-brokered Internet agenda: anonymous netizen opinion spreads to important agendas on the Internet through major online rippling channels such as blogs. , personal homepages, and Internet bulletin boards. 2) Dissemination of the agenda on the Internet: online news or websites report important agendas on the Internet which in turn leads to the dissemination of the agenda to a more online public. 3) Internet-mediated reverse agenda-setting: traditional media report online agendas to the public so that they spread to the offline and online public. However, scientists conclude that the Internetmediated process of agenda-setting or agendabuilding does not always occur in sequence. For example, agendas by traditional media could come to the fore again through online discussion or all three steps could occur simultaneously in a short period. (Kim, 2002)

In conducting qualitative research it is believed that social phenomena cannot be measured by quantification. Many social phenomena are shrouded in hidden meanings, implied or latent meanings, connotations, and inaudible sounds. Reality like this cannot be explained by numbers and then it can be concluded as a social fact. The intensity with the object of study is needed to understand the motive, purpose, or meaning behind an individual's action and thoughts. The mind and mind of the object of study are the focus of attention that every qualitative researcher must dissect. Denzin and Lincoln stated that qualitative researchers use measuring tools, methods, and statistical documents in their research, but only to help better understand the phenomenon under study, not to read phenomena from complex statistical methods such as paths, regression, and linear analysis (Denzin, 2009).

Situations or social realities are free to talk about themselves and the task of the researcher is enough to listen and describe what happened. Ethnomethodology tries to avoid attempts to construct a reality that is legitimized by the scientific method. Attempts to arbitrarily use the scientific method are attempted to be countered so that others can have a say for themselves and not just resign themselves to foreign classifications. As a necessity, ethnomethodological research requires a long time and sufficient energy to be able to be absorbed into the daily life of the object of study. The data obtained were not only formal, but researchers were able to capture nuances, context, and non-verbal findings.

Interviews are used as a way of obtaining data in qualitative studies. Interviews are considered capable of extracting information and opinions that can be used as assumptions of the truth of reality. Opinion from the source is believed to be an honest acknowledgment of the mind which is used as the motive for individual social actions. However, interviewing in ethnomethodology is understood in a somewhat different sense. Formal interviews are important as a means of obtaining data but cannot be used as a source. Data is not only the result of the interviewee's answers to the questions posed by the interviewer, but the interview process itself is data that must be analyzed as well.

Efforts to research by observation are carried out by observing the phenomenon of journalists in carrying out journalistic duties to carry out their function as a watchdog towards the public, power, and the media. Some 
government activities, public activities, and the media in carrying out the functions of the press also do not escape the scrutiny of the media. Besides, research carried out using documentation in the form of artifacts that are stored digitally and in print is carried out to be part of the analysis and to reveal findings related to the role of the media in carrying out the watchdog function. Triangulation through the observation stage of journalistic activities and the birth of journalistic works by the media, interviews with many sources such as journalists or journalistic practitioners, and documentation in the form of digital and printed artifacts are the main part of the research carried out.

\section{RESULTS AND FINDING}

The research was carried out on events involving the media such as Tomy Winata's lawsuit against Tempo, the activities of journalists who were involved in trying to escape Setya Novanto when he was being hunted down by the Corruption Eradication Commission, and the media agenda for efforts to help Lutfi Alfiandi did not become victims of violence. findings obtained through triangulation of digital and printed artifacts, observations, and interviews.

Attempts to show the abuse of power by the press, among others, was carried out by Tirto.id by telling a story about a grim story about the independence of the press and journalists in front of practical politics and politicians, which involved a media person named Hilman Mattauch. Hilman was also revealed to be an important figure in the case of Setya Novanto's disappearance when he was being hunted down by the Corruption Eradication Commission. It was revealed that before the Setya Novanto accident, Hilman was stopped by Metro TV on 16 June 2016, he was re-assigned as of 7 November 2016. Setya Novanto, who disappeared from the monitoring of the Corruption Eradication Commission, has become a public concern. Wednesday night (16/11/2017), when the Corruption Eradication Commission investigators came to his residence at Jalan Wijaya XIII, Kebayoran Baru, South Jakarta, Setya Novanto suddenly disappeared. The next day, Thursday (17/11/2017), he reportedly had an accident when he was leaving for the Metro TV Studio in Kedoya, West Jakarta.

The car he was boarding was the Toyota Fortuner B 1732 ZLO, which hit a power pole in Permata Hijau, South Jakarta. The car driver is Hilman Mattauch, who is known to be a journalist for Metro $T V$, but with his close relationship with the Speaker of the DPR, it is known that he eventually became Chairman of the DPR's Press Room. The overlap between the journalist profession and his closeness to Setya Novanto has resulted in him being very deeply involved. Even based on digital artifacts and print media, it is known that in the end Hilman Mattauch was involved too far in trying to hide Setya Novanto, who is known as a slick politician. Although in the end it was discovered that Hilman Mattauch, based on the research he conducted, was a figure who was not caught up in the law even though it was known that his involvement in the Setya Novanto case was too far away.

His name immediately came into the spotlight for driving the wretched Fortuner. Moreover, a few moments before the accident Hilman Mattauch argued that he had just had a direct telecon with the Speaker of the House of Representatives on Prime Time Metro TV, but it is known that Hilman Mattauch and Setya Novanto were trying to escape the attack by many Corruption Eradication Commission officers. Meanwhile, Metro $T V$ tried to explain the problems that occurred. Don Bosco Salamun, Chief Editor of Metro TV, clarified the existence of Hilman and Novanto. He admitted that he only found out about Hilman and Novanto after the accident at Permata Hijau was widely reported. He gave a short answer that his party only found out later and stated that Metro $T V$ did not tolerate and would take firm action if a violation of the journalistic code of ethics and internal regulations of Metro $T V$ was found.

Based on the incident involving journalists and these powers, it can be seen that the media is too deeply involved with the sources who cannot carry out their functions properly. As a journalist, the journalist who is known to have the assignment area of Metro $T V$ in West Jakarta with the status of a contributor has been part of the abuse of media 
authority by being involved in efforts to hide fugitives from the Corruption Eradication Commission. The proximity of journalists and sources who are too far away has resulted in journalists not carrying out their function as journalists, but becoming the collaborators of the sources and it is known that these sources are involved in legal cases of corruption in eKTP activities that harm the state.

Meanwhile, for digital artifacts, Andreas Harsono stated that he had an interesting story about the Tempo versus Tomy Winata dispute. Two days after the Tempo office was demonstrated by Tomy's supporters, I sat at the table with one of the Tempo editors. We compare what we hear about the incident. It's sad. Bambang Harymurti, Chief Editor of Tempo, was insulted by the demonstrators. The head was punched, the stomach was punched. The demonstrators were angry with intimidation. The editor of Tempo said that the beatings of Bambang and other Tempo journalists had to be countered with political movements. Not by force. Not even with diplomacy.

According to him, journalists should not believe in violence. Journalists should also not trust people who offer violence. Regarding his latest statement, there was a community group that offered assistance to Tempo journalists if they needed security. According to him, this offer is included in the category of violence assistance. Then, why not diplomacy? Don't many Indonesian media settle their disputes with diplomacy? The answer is that this thuggery endangers not only press freedom but also the democratization process. Diplomacy allows thuggery to come back.

According to Ahmad Taufik's testimony, a Tempo journalist who was at the police station with Bambang, David Tjioe also lectured Bambang that as the commander, he must be responsible for Tempo's news. Tjioe even threatened Bambang, he would shoot Bambang Harimurti dead. Meanwhile, in his confession, David Tjioe denied this version of the allegations. He told Andreas Harsono that he did not beat Bambang and did not issue the sentence. He said, how could he beat anyone in front of the police? According to him, Bambang and Taufik were only pushed, not beaten.
Based on a number of artefacts from digital media and print media, it can be seen that in the end Tempo lost in court even though he had the power of the media to shape public opinion through the media setting agenda, but Tempo was defeated in the court process by having to pay a fine and Ahmad Taufik was imprisoned. Andreas Harsono stated, was it true that Tomy Winata three months before the fire submitted a proposal to renovate the Tanah Abang Market worth $\mathrm{Rp}$ 53 billion, as written by Tempo? Is this the most important information in Tempo's report entitled, There is Tomy in Tenabang. This information seems to indicate that the fire could have been started by Tomy's group. In this reporting, which is also an element of burdens for Tempo, Tempo persisted in not revealing the source of the news in the incident. In this incident, it was explained that the power of the media through the news to carry out the watchdog function was not exercised in accordance with the press activities that should have been carried out by the media.

Meanwhile, the media setting agenda in carrying out the role of watchdog was also carried out in the case of Lutfi Alfiandi, an STM student who was detained for carrying out a demonstration with STM students. As revealed in the narrative, which was presented by Mata Najwa (Shihab, 2020) it is known that the role of the media, including a number of other media, has also followed the case of rejection of the revision of the KPK Law. Among other things, the agenda was related to the arrest of Lutfi Alfiandi, which was finally revealed by the media. There is an agenda for media settings in an effort to reject the revision of the KPK Law and the case of Lutfi Alfiandi's arrest.

The articles accused of Lutfi Alfiandi have the potential to put Lutfi in jail for 7 years. For Andi Oku, an advocate from LBH Kobar who is Lutfi's legal advisor, saying that was unfair. Andi Oku stated that in the trial there were no facts that corroborate Lutfi to throw the throws. Meanwhile, Lutfi's biological mother stated that she really missed her child and said softly that she only wanted Lutfi to be free. Lutfi Alfiandi, the bearer of the red-and-white flag during the 
demonstration stated that he was forced to admit that he threw stones during an examination. The victim stated that he did not do that. Lutfi Alfiandi was then beaten and electrocuted by the officers conducting the investigation. So, said Lutfi Alfiandi, he finally admitted that he was under duress, under pressure in the form of beatings and electric shocks he had experienced. Regarding Lutfi Alfiandi's confession, the media also conveyed a police statement. Police Chief Commissioner Yusri Yunus, Head of Public Relations at Polda Metro Jaya, explained that when the incident occurred, the police carried out activities professionally and in accordance with the SOP or code of conduct in the police department.

According to media artifacts, the interviews conducted, complemented by observations in the event the media watchdog function of the Lutfi Alfiandi case were not completely successful, but they did not completely fail because even though they were charged with a sentence of seven years, in the last trial, Lutfi Alfiandi, whose confession was about torture. and the shock that he experienced during the police investigation was eventually released from the sentence with a sentence of four months in prison. Thus, Lutfi Alfiandi, who sat as the defendant, was released at the last trial. However, the media monitoring function to reject the revision of the KPK Law was unsuccessful due to the fact that the revision of the KPK Law by cutting a number of KPK powers and the establishment of the Corruption Eradication Commission Supervisory Board has resulted in the KPK being paralyzed and unable to carry out its functions as previously implemented by the press.

\section{CONCLUSION}

The results of the research conducted found some findings:

1. The implementation of the watchdog press to reveal Tomy Winata in Tanah Abang was carried out by Tempo, although the result was that Tempo suffered the consequences of being defeated at the court table by the lawsuit filed by Tomy Winata.
2. The implementation of watchdog in law enforcement efforts by the Corruption Eradication Commission (KPK) was carried out against the power of the media which involved Hilman Mattauch from Metro TV and was exposed by the media.

3. The police's arrest and torture of Lutfi Alfiandi led to the implementation of agenda-setting by the media in the role of a watchdog which succeeded in making the victim who was sentenced to seven years in prison get public sympathy and was released when the verdict was handed down by the panel of judges.

\section{BIBLIOGRAPHY}

Adorno, T. (1976). Culture Industry Reconsidered (Résumé über Kulturindustrie). New German Critique, No. 6 (Autumn, 1975), pp. 12-19.

Balmas M., S. T. (2010). Candidate image in election campaigns: attribute agenda setting, affective priming, and voting intentions . International Journal of Public Opinion Research, Vol. 22 No. 2.

Bartels, L. M. (1996). Politicians and the Press: Who Leads, Who Follows? Paper presented at the APSA. San Francisco: APSA.

Berkowitz, D. (1992). Who Sets the Media Agenda? The Ability of Policymakers to Determine News Decisions. In D. Kennamer (Ed.), Public, Opinion, the Press and Public Policy. Westport: Westport, CT: Praeger.

Cobb, R. E. (1971). The politics of agendabuilding: An alternative perspective for modern democratic theory. The Journal of Politics, 33: 892-915.

Cohen, B. (1963). The Press and Foreign Policy. Princeton, NJ: Princeton University Press.

David H. W., J. C. (2017). The Media Agenda: Who (or What) Sets It? The Oxford Handbook of Political Communication. Oxford: Oxford University.

Denzin, N. L. (2009). Handbook of Qualitative Research. California: Thousand Oaks, CA: Sage Publications. 
Harsono, A. (2003, 2 10). Majalah Trust. Retrieved 7 10, 2020, from Trust: http://www.andreasharsono.net/2003/0 2/tempo-vs-tomy-winata.html

Kim, S. S. (2002). Think about it this way: Attribute agenda-setting function of the press and the public's evaluation of a local issue. Journalism \& Mass Communication Quarterly, 79, 7-25.

Kohut, A. (2001). Public Support for the Watchdog is Fading. New York: Columbia Journalism Review.

Kosicki, G. (1993). Problems and Opportunities in Agenda-Setting Research" (PDF) . Journal of Communication, 43 (2): 100-127.

Lang, G. L. (1981). Watergate An exploration of the agenda-building process in Mass Communication Review Yearbook Eds Wilhoit, $G$ C, de Bock, H. California: Sage, Beverly Hills, CA.

McCombs, M. (1993). The Evolution of Agenda-Setting Research: Twenty-Five Years in the Marketplace of Ideas. Journal of Communication, 43 (2): 58 67. doi : $10.1111 / \mathrm{j} .1460$ 2466.1993.tb01262.x.

McCombs, M. E., \& Shaw, D. L. (1972). The Agenda-Setting Function of Mass Media. Public Opinion Quarterly, Public Opinion Quarterly 36 (2): 176.

Najwa, M. (2020, Januari 23). Narasi. Retrieved Maret 20, 2020, from Mata Najwa:

https://www.youtube.com/watch?v=tJ $8 \mathrm{I} \mathrm{IGeF} 4 \& \mathrm{t}=3 \mathrm{~s}$

Peter V.A., T. G. (2014). Mediatization and Political Agenda-Setting: Changing
Issue Priorities? Mediatization of Politics, 200-220.

Reese, S. (1996). Journalism Research And The Hierarchy Of Influences Model: A Global Perspective. Brazilian Journalism Research, Volume 3 Number 2 - Semester 2.

Shihab, N. (2020, 1 24). Mata Najwa. Retrieved 8 3, 2020, from Mata Najwa: https://www.youtube.com/watch? $\mathrm{v}=\mathrm{M}$ gJ02AJhTxE

Soekowati, G. (2019). Existence Of Media In Implementing The Role Of Watchdog In The Case Of Land Equipment For The Development Of New Yogyakarta International Airport. Library Philosophy and Practice (e-journal), https://digitalcommons.unl.edu/libphilp $\mathrm{rac} / 3743 /$.

Tempo. (2004, March 18). nasional.tempo.co. Retrieved June 17, 2020, from Tempo.co: https://nasional.tempo.co/read/40772/h akim-pn-jakarta-pusat-kabulkangugatan-tommy-winata

Tirto.id. (2017, November 16). Tirto.id. Retrieved Desember 17, 2018, from Tirto.id: https://tirto.id/hilman-paperjejak-hilman-mattauch-di-parlemenmetro-tv-cAey

Wilson, R. A. (2009). How to Situate Cognition: Letting Nature Take Its Course, in Philip Robbins and Murat Aydede (eds.), The Cambridge Handbook of Situated Cognition. Cambridge: Cambridge University Press. 